\title{
Sustainable Agile Project Management in Complex Agriculture Projects: An Institutional Theory Perspective
}

\author{
Hao Dong ${ }^{a *}$, Nicholas Dacre ${ }^{a}, \&$ Adrian Bailey ${ }^{b}$
}

\author{
${ }^{\text {a }}$ University of Southampton Business School, University of Southampton, Southampton, SO17 1BJ, UK \\ ${ }^{\mathrm{b}}$ University of Exeter Business School, University of Exeter, Exeter, EX4 4PU, UK \\ * Corresponding Author: h.dong@soton.ac.uk
}

\begin{abstract}
Complex agriculture projects directly affect the welfare of over half the world's population, are a key Sustainable Development Goal (SDG), and account for the single most extensive human activity across $40 \%$ of the world's surface. Furthermore, they are highly susceptible to environmental, social, and economic pressures such as climate change, cyclical pandemics, market disruptions, and diminishing arable land. These issues are also becoming increasingly vital in dint of the fact that population growth is placing increasing pressure on sustainable priorities. However, a recent scientometric review indicates a significant paucity in the extant literature on agriculture projects, with a pressing need for further research to examine sustainable project management practices from an institutional perspective. This research, therefore, aims to respond to this gap in the literature by drawing on Institutional Theory through a multi-case study of Agriculture Co-operative Institutions (ACIs). These are often viewed as valuable vehicles to deliver agricultural projects which can benefit communities, especially in emerging markets. Initial findings from two rounds of fieldwork as well as an extensive literature review suggest that ACIs as value-based organisations embedded within institutional contexts help stimulate elements of agility in project management processes, to deliver sustainable outcomes for their members and external stakeholders. Agile ACI project managers can also stimulate innovative outcomes across broader sustainable agriculture projects. It is the aim of this research also to undertake a larger cross-country comparison with international research cases. Therefore, this study will aim to not only contribute to critical project management discourse and knowledge but also to uncover agile project management practices for future pressing policy development and implementation to help foster greater sustainable agriculture project processes.
\end{abstract}

Keywords: Project Management, Sustainable, Co-Operative, Coop, Sustainability, Agile, Agriculture, Institutional Theory.

\section{Citation}

Dong, H., Dacre, N., \& Bailey, A. (2021). Sustainable Agile Project Management in Complex Agriculture Projects: An Institutional Theory Perspective. Advanced Project Management, 21(3). https://dx.doi.org/10.2139/ssrn.3829912

\section{Introduction}

A recent scientometric review of massive bibliographic records across combined databases (Web of Science \& Scopus) demonstrates increasing academic focus on project management and sustainability, involving a wide selection of sectors including agriculture and rural development (De Toledo et al., 2019). Sustainability and responsible management are also increasingly becoming important for future project practitioners (Dacre et al., 2019; Gkogkidis \& Dacre, 2020; Tite et al., 2021). In the context of agricultural development, according to Smith (1984, p.1), "a project is a unique operation 
to modify the means of production...from an individual farmer constructing a large new dairy unit, to a government department executing large scale, conservation works, or even to a project in which the major items are administrative rather than physical, such as the reorganisation of part of the state's agricultural service".

However, despite that agriculture and rural projects directly affect the welfare of over half of the world's population, the sustainability of which have attracted decades-long attention and effort (e.g. U.N. Sustainable Development Goals) from socioeconomists, policymakers, and many other stakeholders (United Nations, 2015; Ridley-Duff \& Wren, 2018; World Bank, 2019), there is a noticeable under-representation of related research outputs from a project management perspective.

Research undertaken across publications of specialist project management journals (the International Journal of Project Management and the Project Management Journal) over 15 years, Themistocleousa \& Wearne (2000) suggests that academic studies on project management processes in the agriculture sector failed to reflect the relative importance and real-world impacts of agriculture development, specifically in terms of both its contributions to GDP and its critical role in sustaining and addressing global significant socioeconomic issues.

This study therefore seeks to address this gap in knowledge across the extant project management literature by adopting an interdisciplinary research approach to investigate agriculture-related projects through the lens of institutional theory across the paradigm of agile project management approaches.

It is also noteworthy to examine how value-based organisations, such as co-operatives, in contrast to traditional organisations, succeed in delivering both commodity products/services and associated unique characteristics of 'social, environmental, and longterm economic sustainability' as project deliverables (Pullman \& Dillard, 2010, p.744; see also Ostrom, 1990; Smith, 1984). Especially at a point where the Covid-19 pandemic has caused global disruptions highlighting social and economic challenges (Wang et al., 2020). Furthermore, in order to better facilitate agriculture-related sustainability and innovation, Shepherd et al. (2018) recently called for further academic investigation incorporating agile project management and organisational models.

This research therefore attempts to rigorously review the underrepresented agriculture project management practices across Agriculture Cooperative Institutions (ACIs) through multiple cases in rural China by comparing and identifying their common and possibly distinctive agile project management approaches and other organisational processes. Consequently, the leading research question for this study is summarised as: how can agriculture co-operative institutions manage agriculture projects with agility processes in order to refine sustainable outcomes? The authors aim to generate a novel and interdisciplinary contribution to project management knowledge, as well as to provide practice-based management and policy development for future application.

\section{Agriculture Co-Operative Institution Projects}

The International Co-operative Alliance's Cooperative Identity Statement defines a co-operative as "an autonomous association of persons united voluntarily to meet their common economic, social, and cultural needs and aspirations through a jointlyowned and democratically-controlled enterprise" (ICA, 2018).

ACIs refer to farmer-owned and democratically controlled enterprises, which value social and cultural needs (Ridley-Duff, 2018). ACIs play a vital role in sustainable and innovative agriculture produce and rural development of developing countries like China (Dong, 2019) and developed countries (Luo et al., 2020).

They offer technological and institutional innovations and help to sustain economic activities throughout the community (Bijman, 2018; Bailey et al., 2021). ACIs have been witnessed to contribute to the improvement in profitability, quality, and efficiency of agriculture (Liang \& Hendrikse, 2013) and promote innovation in the industry resulting in rural development and poverty alleviation (Bernard \& Spielman, 2009; Oelofse, 2010; Dong, 2019).

There are numerous ACIs in China, which are also referred to as Specialised Farmers Co-operatives, under recent supportive legislations and policy, which initiated a considerable period of growth - 
from around 150,000 ACIs representing 24 million rural households in 2004 (MAPRC, 2007) to beyond 2.2 million registered ACIs covering half of the country's rural population just 15 years later (MAPRC, 2019a, 2019b). In the E.U., ACIs owns a $40 \%$ market share of agricultural production on average (Bijman et al., 2014).

As a response to the ever-changing conditions, including socio-economic crises, the governance mechanisms of ACIs across the world have had to adapt to changing environments and pressing priorities (Lizarralde, 2010; Chaddad \& Iliopoulos, 2013; Bijman et al., 2014). For example, a recent case study exploring the innovation of the key ACI and their leading partner Riverford, which is a major UK organic retailer, Bailey et al. (2021) suggests that ACIs must sustain outputs facing post-Brexit challenges. However, based on extensive literature reviews (Dong, 2019; Luo et al., 2020), few attempts have been made to examine ACIs in the context of agriculture projects from a project management perspective, with even fewer devoted to their agility across rising socio-economic challenges.

Governments and academics have recognised the importance to achieve sustainable, responsible, and innovative development through ACIs as a form of organising individual rural business (Deng et al., 2010; Yan \& Chen, 2013; Dong, 2019).

Coincidentally, this approach facilitates addressing one of the three main elements of significant underrepresentation of agriculture-related project management, as pointed out by Themistocleousa \& Wearne (2000), in dint of the nature of dispersion and disparity of project stakeholders.

The ensuing two reasons are: lack of scholarly attention devoted to project management in highly agriculture active countries and regions, and that non- construction projects in the agriculture sector are often neglected (ibid), can also be examined through the interdisciplinary nature of the research team and examination processes through the lens of institutional theory.

\section{Institutional Theory}

Drouin \& Besner (2012) previously asserted the importance of understanding project management from the perspective of host organisations and spurred a series of research papers on this issue in the
International Journal of Managing Projects in Business. Equally, there has been an increasing academic focus on exploring sustainable and innovative project processes through institutional lenses, in that projects are embedded in their institution fields and interact with the institutions (Winch \& Maytorena-Sanchez, 2020). For example, multiple tensions of projects and institutions "arise as the shadow of the past (legacies of previous projects) and create tensions for continuity" (Uriarte et al., 2019, P.321).

The conventional approach in extant project management literature of recognising project as an individual and unique concept is hence criticised, arguing that projects should not be defined by complexity or time-boundedness but should be considered as complex norms which constitutes a continuous and repeating improvement of institutions (Biesenthal et al., 2018; Harvey \& Aubry, 2018).

Organisational support and synchronised individual behaviours are required to achieve successful projects to receive optimised performance and investments (Eve, 2007), with the improved alignment of knowledge and requirements to better cope with the diversity and complexity associated with project management (Bresnen, 2016). Picciotto (2020) agrees and calls for a new project management approach with a more flexible assessment methodology covering complex agriculture projects and organisations undertaken by ACIs.

There is also a need for further theoretical development and empirical examination of agile project management through an institutional perspective (Conforto \& Amaral, 2016; Hobbs \& Petit, 2017; Lechler \& Yang, 2017; Mergel et al., 2020).

Some recent attempts were also made to explore ACIs through the lens of institutional theory, but the majorly were limited to those in the U.S. (Pullman \& Dillard, 2010; Grashuis \& Cook, 2018; Dong 2019), and are mainly theorised through transaction-cost economics (Bijman, 2018) rather than a project management powerline.

Institutional perspectives explain both individual and organisational actions as powerful sources of change (Dacin et al., 2002) as organisations are 
considered under the influence of normative and cognitive pressures (DiMaggio \& Powell, 1983; Teo et al., 2003; Corbett et al., 2018).

The embeddedness of ACIs into institutional logics is critical for their sustaining because it is the enabler to recognise and utilise the environments' specific complexity to deliver improved performance (Jack \& Anderson, 2002). This research adopts and develops a cross-level institutional environment model (Figure 1) proposed by Corbett et al. (2018) to examine the case ACIs' project management under conflicting pressures.

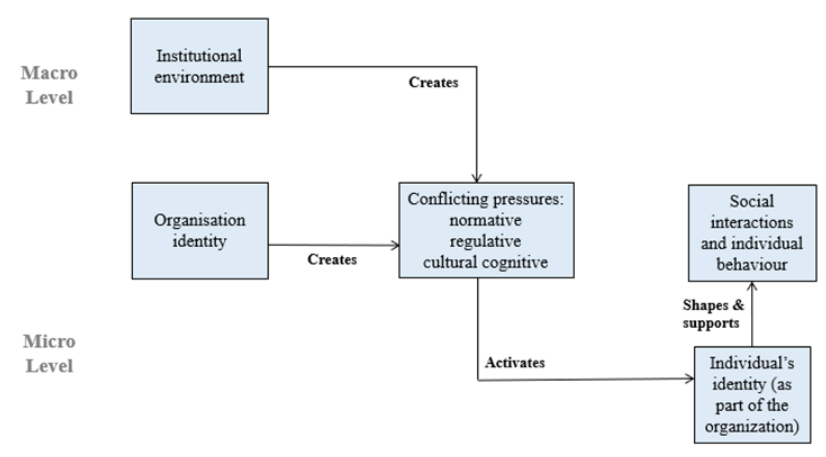

Figure 1: Cross-Level Model of Institutional Logic (adapted from Corbett et al., 2018)

\section{Discussion \& Future Research}

This research has hitherto applied a multiple-case study approach to conduct an empirical investigation of a contemporary phenomenon in real-life contexts with robust evidence from compound sources (Yin, 2009) with no explicit boundaries between the complex phenomenon and their contexts of interaction (Sayer, 1992; Easton, 2009), such as those found in ACIs, which are deeply embedded in the local institutional environment and other community contexts (Po, 2008; Zhao \& Gijselinckx, 2011).

The applied case comparison approach is especially suitable for such complicated socio-economic phenomena where the investigator has no control over the events related to the case organisations (Feagin et al., 1991; Yin, 2009). Following a systematic literature review on Chinese ACIs, cases have been selected according to purposive theoretical criteria (Karmel \& Jain, 1987; Yin, 2003). Specifically, three ACIs from different regions of Mainland China with relevant project experience, which underpin the empirical focus for this multiplecase study.
The primary data collection has adopted prior established project management empirical approaches through semi-structured interviews with various participants (Reynolds \& Dacre, 2019; Dacre et al., 2020), including individual members, project and general managers at different levels of hierarchy, customers, local governors, and associated stakeholders. Internal documents and interviewer observations are used as supplementary data. The research utilises qualitative interviews to gain access to interviewees' knowledge and expert insights through purposive personal conversations to generate rich data and to uncover the reflections and experiences which are often ignored or misrepresented through other approaches (Silverman, 2006).

The total collected data will be coded in three rounds using a constant comparative method (Glaser, 1965), blending empirical and theoretical codes (from institutional theory and angles relevant to agile project management). This approach enables themes to be first developed through an iterative process of coding. Then sub-themes can be applied according to categories derived from a literature review, and third, the codes will be grouped under overarching theoretical categories.

Two of the three phases of data collection have already been undertaken, with a total of

25 interviews, each lasting between 45-90 minutes. Consuming transcription and translation of the interview data so far, a third field visit is planned to capture additional data, which has become especially relevant as a result of the Covid-19 global pandemic.

Additional interviews will employ a combination of face-to-face or digital/virtual communication, where appropriate. Illustrative quotations for each code will be placed in relevant corresponding analyses. Informal interviews, accompanied observations, and field notes will be used as an additional supplement source of information to reach triangulation, enhancing the qualitative case study's fidelity and reliability (Decrop, 1999; Yin, 2009). The authors will also incorporate archived cases from relevant international settings to foster cross-country case comparison, across works of reputable leading peer scholars, for example, those of Prof. J. Bijman (Wageningen), Prof. M. Pullman (Portland \& Groningen), Prof. Z. Wu (Oregon State), Prof. R. Ridley-Duff (Sheffield Hallam), and Prof. T.S. Martins (UFPR). 


\section{References}

Bailey, A. R., Fu, J., Dong, H., \& Martins, T. S. (2021). Sustaining supply chain relationships for co-operative success: the case of South Devon Organic Producers Cooperative (UK). International Food and Agribusiness Management Review, 24(1), 162-178. https://doi.org/10.22434/IFAMR2020.0062

Bernard, T. \& Spielman, D. J. (2009) 'Reaching the rural poor through rural producer organizations? A study of agricultural marketing cooperatives in Ethiopia', Food policy, 34(1), pp. 60-69.

https://doi.org/10.1016/j.foodpol.2008.08.001

Biesenthal, C., Clegg, S., Mahalingam, A., \& Sankaran, S. (2018) 'Applying institutional theories to managing megaprojects', International Journal of Project Management, 36(1), pp. 43-54.

https://doi.org/10.1016/j.ijproman.2017.06.006

Bijman, J. (2018) 'Exploring the sustainability of the cooperative model in dairy: The case of The Netherlands', Sustainability, 10(7), Article 2498.

https://doi.org/10.3390/su10072498

Bijman, J., Hanisch, M. \& van der Sangen, G. (2014) 'Shifting Control? The Changes of Internal Governance in Agricultural Cooperatives in the EU', Annals of Public and Cooperative Economics, 85, pp. 641-661.

https://doi.org/10.1111/apce.12055

Bresnen, M. (2016) 'Institutional development, divergence and change in the discipline of project management', International Journal of Project Management, 34(2), pp. 328-338. https://doi.org/10.1016/j.ijproman.2015.03.001

Chaddad, F. \& Iliopoulos, C. (2013) 'Control Rights, Governance, and the Costs of Ownership in Agricultural Cooperatives', Agribusiness, 29(1), pp. 3-22.

https://doi.org/10.1002/agr.21328

Conforto, E.C. \& Amaral D.C. (2016) 'Agile project management and stage-gate model - A hybrid framework for technology-based companies', Journal of Engineering and Technology Management, 40, pp. 1-14.

https://doi.org/10.1016/j.jengtecman.2016.02.003

Corbett, J., Webster, J., \& Jenkin, T.A. (2018) 'Unmasking Corporate Sustainability at the Project Level: Exploring the Influence of Institutional Logics and Individual Agency', Journal of Business Ethics, 147, pp. 261-286. https://doi.org/10.1007/s10551-015-2945-1

Dacin, M.T., Goodstein, J., \& Scott, W. R. (2002) 'Institutional Theory and Institutional Change: Introduction to the Special Research Forum', Academy of Management Journal, 45(1), pp. 45-56.

https://doi.org/10.2307/3069284
Dacre, N., Kockum, F., \& Senyo, PK. (2020). Transient Information Adaptation of Artificial Intelligence: Towards Sustainable Data Processes in Complex Projects. British Academy of Management, Manchester, UK. https://dx.doi.org/10.2139/ssrn.3813559

Dacre, N., Senyo, PK., \& Reynolds, D. (2019). Is an Engineering Project Management Degree Worth it? Developing Agile Digital Skills for Future Practice. Engineering Education Research Network, Coventry, UK. https://dx.doi.org/10.2139/ssrn.3812764

De Toledo, R.F., Miranda Junior, H.L., Farias Filho, J.R., Costa, H.G. (2019) 'A scientometric review of global research on sustainability and project management dataset', Data in Brief, 25, Article 104312. https://doi.org/10.1016/j.dib.2019.104312

Decrop, A. (1999) 'Triangulation in Qualitative Tourism Research', Tourism Management, 20(1), pp. 157-161. https://doi.org/10.1016/So261-5177(98)00102-2

Deng, H., Huang, J., Xu, Z., \& Rozelle, S. (2010) 'Policy Support and Emerging Farmer Professional Cooperatives in Rural China', China Economic Review, 21(4), pp. 495507. https://doi.org/10.1016/j.chieco.2010.04.009

DiMaggio, P.J. \& Powell, W.W. (1983) 'The iron cage revisited: institutional isomorphism and collective rationality in organizational fields', American Sociological Review, 48, pp. 147-16o.

https://doi.org/10.2307/2095101

Dong, H. (2019) Contemporary Agricultural Co-operatives in China: A Multi-case Comparison of Tea Co-operatives and Their Supply Chains. PhD thesis. University of Exeter. Available at:

https://ore.exeter.ac.uk/repository/handle/10871/39740

Drouin, N. \& Besner, C. (2012) 'Projects and organisations: Adding rungs to the ladder of understanding project management and its relationship with the organisation', International Journal of Managing Projects in Business, 5(2), pp. 175-179.

https://doi.org/10.1108/17538371211214888

Easton, G. (2010). Critical realism in case study research. Industrial marketing management, 39(1), 118-128. https://doi.org/10.1016/j.indmarman.2008.06.004

Eve, A. (2007) 'Development of project management systems', Industrial and Commercial Training, 39(2), pp. 85-90. https://doi.org/10.1108/00197850710732406

Feagin, J. R., Orum, A. M., \& Sjoberg, G. (Eds.). (1991). A case for the case study. UNC Press Books. 
Gkogkidis, V., \& Dacre, N. (2020). Exploratory Learning Environments for Responsible Management Education Using Lego Serious Play. SBS Working Paper Series. https://dx.doi.org/10.2139/ssrn.3813349

Glaser, B. G. (1965) 'The constant comparative method of qualitative analysis', Social Problems, 12(4), pp. 436-445.

Grashuis, J. \& Cook, M. (2018) 'An examination of new generation cooperatives in the upper midwest: successes, failures, and limitations', Annals of Public and Cooperative Economics, 89(4), pp. 623-644. https://doi.org/10.1111/apce.12211

Harvey, J. \& Aubry, M. (2018) 'Project and processes: a convenient but simplistic dichotomy', International Journal of Operations \& Production Management, 38(6), pp. 1289-1311. https://doi.org/10.1108/IJOPM-01-20170010

Hobbs, B. \& Petit, Y. (2017) 'Agile methods on large projects in large organizations', Project Management Journal, 48(3), pp. 3-19.

https://doi.org/10.1177/875697281704800301

ICA (2018) Co-operative Identity, Values and Principles. Geneva: International Co- operative Alliance. Available at: https://ica.coop/en/whats-co-op/co-operative-identityvalues-principles (Accessed: 21 September 2020)

Jack, S.L. \& Anderson, A.R. (2002) 'The Effects of Embeddedness on the Entrepreneurial Process', Journal of Business Venturing, 17(5), pp. 467-487. https://doi.org/10.1016/So883-9026(01)00076-3

Karmel, T.S. \& Jain, M. (1987) 'Comparison of Purposive and Random Sampling Schemes for Estimating Capital Expenditure', Journal of the American Statistical Association, 82(397), pp. 52-57. https://doi.org/10.1080/01621459.1987.10478390

Lechler, T.G. \& Yang, S. (2017) 'Exploring the role of project management in the development of the academic agile software discourse: A bibliometric analysis', Project Management Journal, 48(1), pp. 3-18.

https://doi.org/10.1177/875697281704800101

Liang, Q. \& Hendrikse, G. (2013) 'Core and Common Members in the Genesis of Farmer Cooperatives in China', Managerial and Decision Economics, 34(3/5), pp. 244257. https://www.jstor.org/stable/23464304

Lizarralde, G. (2010) 'Decentralizing (re)construction: Agriculture cooperatives as a vehicle for reconstruction in Colombia', in Lyons, M., Schilderman, T., \& Boano, C. (ed.) Building Back Better Delivering people-centred housing reconstruction at scale. Practical Action Publishing, pp. 191-213.
Luo, J., Han, H., Jia, F., \& Dong, H. (2020) 'Agricultural Co-operatives in the Western World - A Bibliometrics Analysis', Journal of Cleaner Production, 273, Article 122945. https://doi.org/10.1016/j.jclepro.2020.122945

MAPRC. (2007) 中央一号文件对农民专业合作社发展提出 要求 (The No. 1 Document puts requirements on the development of SFCs). Ministry of Agriculture of the People's Republic of China, Beijing.

\section{MAPRC. (2019a) 国家农民合作示范社发展指数}

(Development Index of National Exemplar Farmer Cooperatives). Ministry of Agriculture of the People's Republic of China, Beijing.

\section{MAPRC. (2019b) 农业农村部办公厅全于推介全国农民合作} 社典型案例的通知 (MAPRC's Announcement on

Promoting National Exemplar Farmer Cooperatives). Ministry of Agriculture of the People's Republic of China, Beijing.

Mergel, I., Ganapati, S., \& Whitford, A.B. (2020) 'Agile: A new way of governing', Public Administration Review, 81, pp. 161-165. https://doi.org/10.1111/puar.13202

Oelofse, M., Hogh-Jensen, H., Abreu, L.S., Almeida, G.F., Hui, Q., Sultan, T., \& de Neergaard, A. (2010) 'Certified Organic Agriculture in China and Brazil: Market Accessibility and Outcomes Following Adoption', Ecological Economics, 69, pp. 1785-1793. https://doi.org/10.1016/j.ecolecon.2010.04.016

Ostrom, E. (1990) Governing the Commons. The Evolution of Institutions for Collective Action. Cambridge University Press: Cambridge.

Picciotto, R. (2020) 'Towards a "New Project Management" movement? An international development perspective', International Journal of Project Management, 38(8), pp. 474-485.

https://doi.org/10.1016/j.ijproman.2019.08.002

Po, L. (2008) 'Redefining rural collectives in China: Land conversion and the emergence of rural shareholding cooperatives' Urban Studies, 45(8), pp. 1603- 1623. https://doi.org/10.1177/0042098008091493

Pullman, M.E. \& Dillard, J. (2010) 'Values based supply chain management and emergent organizational structures', International Journal of Operations \& Production Management, 30(7), pp. 744-771. https://doi.org/10.1108/01443571011057326 
Reynolds, D., \& Dacre, N. (2019). Interdisciplinary Research Methodologies in Engineering Education Research. Engineering Education Research Network, Coventry, UK. https://dx.doi.org/10.2139/ssrn.3812769

Ridley-Duff, R. (2018) 'Cooperative social entrepreneurship: reflecting on a decade of embedding cooperative studies in social enterprise courses', Cooperative Education Conference 2018, Manchester, United Kingdom, 1-2 May. http://shura.shu.ac.uk/21020/

Ridley-Duff, R. \& Wren, D. (2018) 'Social enterprise, Sustainable development and the FairShares model', Japanese Journal of Human Welfare Studies, 11(1), pp. 23-42. http://shura.shu.ac.uk/id/eprint/25337

Sayer, A. (1992) Method in social science: A realist approach. 2nd edn. London: Routledge.

https://doi.org/10.1177/030913259301700339

Shepherd, M., Turner, J.A., Small, B., \& Wheeler, D. (2018) 'Priorities for science to overcome hurdles thwarting the full promise of the "digital agriculture" revolution', Journal of the Sciences of Food and Agriculture, 100, pp. 5083-5092.

https://doi.org/10.1002/jsfa.9346

Silverman, D. (2006) Interpreting Qualitative Data. 3rd edn. London: Sage.

Smith, P. (1984) Agricultural Project Management: Monitoring and Control of Implementation. Reprint. Elsevier Applied Science Publishers LTD 2012.

Teo, H.H., Wei, K.K., \& Benbasat, I. (2003) 'Predicting intention to adopt interorganizational linkages: an institutional perspective', MIS Quarterly, 27(1), pp. 19-49. https://doi.org/10.2307/30036518

Themistocleousa, G. \& Wearne, S.H. (2000) 'Project management topic coverage in journals', International Journal of Project Management, 18(1), pp. 7-11. https://doi.org/10.1016/So263-7863(99)ooo30-7

Tite, C. N. J., Pontin, D., \& Dacre, N. (2021). Embedding Sustainability in Complex Projects: A Pedagogic Practice Simulation Approach. Advanced Project Management, 21(2). https://dx.doi.org/10.2139/ssrn.3814008
United Nations (2015) Transforming our world: the 2030 Agenda for Sustainable Development (A/RES/70/1). New York: United Nations Department of Economic and Social Affairs. Available at:

https://sdgs.un.org/publications/transforming-ourworld-2030-agenda-sustainable-development-17981 (Accessed: 22 November 2019)

Uriarte, Y.T., DeFillippi, R., Riccaboni, M., \& Catoni, M.L. (2019) 'Projects, institutional logics and institutional work practices: The case of the Lucca Comics \& Games Festival', International Journal of Project Management, 37(2), pp. 318-330.

https://doi.org/10.1016/j.ijproman.2018.09.001

Wang, H., Dill, S., Zhou, H., Ma, Y., Xue, H., Loyalka, P., Sylvia, S., Boswell, M., Lin, J. \& Rozelle, S. (2020) Off the Epicenter: COVID-19 quarantine controls and employment, education, and health impacts in rural communities. Stanford University Rural Education Action Program working paper 2020.

Winch, G.M. \& Maytorena-Sanchez, E. (2020)

'Institutional projects and contradictory logics: Responding to complexity in institutional field change', International Journal of Project Management, 38(6), pp. 368-378.

https://doi.org/10.1016/j.ijproman.2020.08.004

World Bank (2019) Agriculture \& Rural Development. Available at: https://data.worldbank.org (Accessed 22 November 2019).

Yan, H. \& Chen, Y. (2013) 'Debating the rural cooperative movement in China, the past and the present', The Journal of Peasant Studies, 40(6), pp. 955-981.

https://doi.org/10.1080/03066150.2013.866555

Yin, R.K. (2003) Applications of Case Study Research. Sage.

Yin, R.K. (2009) Case Study Research: Design and Methods. Sage.

Zhao, L. \& Gijselinckx, C. (2011) 'Multi-stakeholder cooperatives in China: a resource mix structure approach', Social Enterprise Journal, 7(3), pp. 259-279. https://doi.org/10.1108/17508611111182403

Advanced Project Management | APROM www.southampton.ac.uk/aprom

The Advanced Project Management research series accepts working conceptual and empirical papers, literature reviews, development papers, technical papers, case studies, and general reviews. Papers of a qualitative, quantitative, or mixed methods nature are welcome, including highly novel research approaches where relevant. Authors retain copyright of their work. The title page should include: Title; Author Name(s); Institution Affiliation(s); Contact Email Address(es); Abstract; and Keywords. Submit your paper as a Word or PDF file to: aprom@southampton.ac.uk 